\title{
Multi-detector CT-angiography is useful in predicting haematoma expansion in patients with acute primary intracerebral hemorrhage
}

\author{
Inger Havsteen ${ }^{1 *}$, Louisa Christensen ${ }^{2}$, Anders Fogh Christensen ${ }^{1}$, Jen Kellberg Nielsen ${ }^{1}$, Serk P Krieger ${ }^{2}$,
} Hanne Christensen ${ }^{2}$

From Danish Society for Emergency Medicine: Research Symposium 2010

Roskilde, Denmark. 20-21 May 2010

\section{Background}

Primary ICH expands in up to $50 \%$ of cases and in these treatment with haemostatic compounds can be potentially beneficial. Spot detection on multi-detector CTangiography (MDCTA) studies may identify ongoing bleeding and thus predict haematoma expansion.

Aim was to assess the frequency, the prognostic impact and haematoma volume increase in patients with positive spot sign in comparison to no spot sign.

\section{Methods}

A non-contrast CT scan (NCCT) and MDCTA was performed in patients with ICH within 3 hours. A NCCT was performed next day. Radiologists reviewed MDCTAs for spot sign and estimated the haematoma volume.

\section{Results}

In $41.4 \%$ spot sign was observed. There was a strong trend that positive spot sign predicted short term mortality $35,9(\mathrm{CI} 0,857 ; 1503,2)(\mathrm{p}=0,041)$ adjusted for age and acute haematoma volume. Mean acute volume was $49,0 \mathrm{ml}$ in patients with spot sign vs. $19,2 \mathrm{ml}$, $(\mathrm{p}=0,001)$. The mean volume increase in patients with spot sign was $12,0 \mathrm{ml}$ corresponding to a $24,5 \%$ increase with spot sign vs. $10,4 \%$ in other patients $(\mathrm{p}=0,009)$.

\section{Conclusion}

Spot sign identifies patients with later haematoma expansion, and may be useful in identifying patients for

\footnotetext{
* Correspondence: seestein@gmail.com

'Department of Radiology, Bispebjerg Hospital, Denmark

Full list of author information is available at the end of the article
}

proof of principle trials in acute $\mathrm{ICH}$, e.g. testing haemostatic compounds or blood pressure reduction.

\section{Author details}

'Department of Radiology, Bispebjerg Hospital, Denmark. ${ }^{2}$ Department of Neurology, Bispebjerg Hospital, Denmark.

Published: 17 September 2010

doi:10.1186/1757-7241-18-S1-P22

Cite this article as: Havsteen et al:: Multi-detector CT-angiography is useful in predicting haematoma expansion in patients with acute primary intracerebral hemorrhage. Scandinavian Journal of Trauma, Resuscitation and Emergency Medicine 2010 18(Suppl 1):P22.
Submit your next manuscript to BioMed Central and take full advantage of:

- Convenient online submission

- Thorough peer review

- No space constraints or color figure charges

- Immediate publication on acceptance

- Inclusion in PubMed, CAS, Scopus and Google Scholar

- Research which is freely available for redistribution

Submit your manuscript at www.biomedcentral.com/submit
C Biomed Central 